\title{
Protection of Erythrocytes against Lipoperoxidation and Anti- inflammatory Effects of Ethanolic Extract of Encelia canescens Lam Leaves in Mice
}

\author{
Fernández-Flores $\mathbf{N}^{1}$, Rojas-Cardenas NF', Vásquez-Quispe AD', Chávez-Flores Juana $\mathrm{E}^{1, *}$, Justil-Guerrero \\ Hugo J', Parreño-Tipian JM', Silva-Correa Carmen R², Villarreal-La Torre Víctor E',*
}

Fernández-Flores $\mathbf{N}^{1}$, RojasCardenas NF ${ }^{1}$, Vásquez-Quispe $A D^{1}$, Chávez-Flores Juana $E^{1, *}$, Justil-Guerrero Hugo J', ParreñoTipian JM', Silva-Correa Carmen $\mathrm{R}^{2}$, Villarreal-La Torre Víctor $\mathrm{E}^{2, *}$

'Facultad de Farmacia y Bioquímica, Universidad Norbert Wiener, PERÚ.

${ }^{2}$ Facultad de Farmacia y Bioquímica, Universidad Nacional de Trujillo, PERÚ.

\section{Correspondence}

\section{Chávez-Flores JE}

Facultad de Farmacia y Bioquímica, Universidad Norbert Wiener, PERÚ.

E-mail: juana.chavez@uwiener.edu.pe History

- Submission Date: 03-05-2020;

- Review completed: 11-05-2020;

- Accepted Date: 20-05-2020

DOI : 10.5530/pj.2020.12.114

Article Available online

http://www.phcogj.com/v12/i4

Copyright

(C) 2020 Phcogj.Com. This is an openaccess article distributed under the terms of the Creative Commons Attribution 4.0 International license.

\begin{abstract}
Background. Encelia canescens Lam is a plant traditionally used in Peru for medicinal purposes, and is attributed antioxidant properties, indicating that it could be used in the prevention of non-communicable diseases. Objective: This study aims to evaluate the protection of erythrocytes from lipoperoxidation and the anti-inflammatory effect of ethanolic extract of $E$. canescens leaves in mice. Materials and methods: Protection from lipoperoxidation was evaluated by inhibition of hemolysis and quantifying malondialdehyde (MDA) concentration against oxidative stress induced with hydrogen peroxide $\left(\mathrm{H}_{2} \mathrm{O}_{2}\right)$ at 200 , $150,100,50$ and $25 \mu \mathrm{g} / \mathrm{mL}$ E. canescens concentrations. The $1 \%$ carrageenan-induced air pouch model was used for evaluated inflammation, where albumin, total proteins, MDA, number and leukocyte differentiation were determined in the exudate, and a histopathological evaluation was performed. The concentrations evaluated were 100, 250 and $500 \mathrm{mg} / \mathrm{kg}$ of $E$. canescens Results: All the concentrations evaluated protected protected erythrocytes from lipoperoxidation ( $p<0.05$ ), being E.D. value $200 \mu \mathrm{g} / \mathrm{mL}$. Regarding anti-inflammatory effect, the albumin, total proteins and MDA values of the treatment groups were lower than carrageenan $1 \%$ group $(p<0.05)$, but, due to less leukocyte migration and presence of macrophages and the histopathological evaluation, the E.D value was $500 \mathrm{mg} / \mathrm{kg}$. Conclusion: Ethanolic extracts of $E$. canescens leaves protect erythrocytes from lipoperoxidation and have dose-dependent anti-inflammatory effects maybe for presence of p-hydroxyacetophenone-derived, and these could be new safer anti-inflammatories.
\end{abstract}

Key words: Encelia canescens Lam, Hemolysis, Malondialdehyde, Lipoperoxidation, Antiinflammatory, Carrageenan.

\section{INTRODUCTION}

Noncommunicable diseases (NCDs) are a health problem that have been the main causes of death for years in low and medium-income countries ${ }^{1}$, generating a negative impact on social and economic development worldwide ${ }^{1-3}$, being the inflammatory processes one of the ones that demand the highest costs worldwide ${ }^{4}$, without having the treatment it can lead to much more serious problems. ${ }^{5}$ The four main types of NCDs are cardiovascular, cancer, lung, and diabetes ${ }^{6}$; in such a way that one of the main causes of these diseases is oxidative stress ${ }^{7}$, a process that shows an imbalance between oxidants and antioxidants and that is the cause of cellular damage. ${ }^{7-9}$

Peru is considered an area of high plant richness and mainly of the Asteraceae, with more than 1613 species ${ }^{10}$ within them we have the species Encelia canescens Lam (E. canescens) known as "coronilla del fraile" or "hierba lingo" that is empirically used for its analgesic ${ }^{11}$, galactophore properties, menstruation regulation ${ }^{12}$, cancer treatment $^{13}$ and viral and bacterial diseases, against urine retention. ${ }^{11}$ This species has triterpenoids ${ }^{14}$, steroids, flavonoids, coumarins, and tannins ${ }^{13}$, being flavonoids, metabolites with potential antioxidant and anti-inflammatory activity ${ }^{15,16}$, but triterpenoids has same anti-inflammatory activities. ${ }^{17,18}$

Antioxidant capacity can be measured in lipoperoxidation processes and also by means of oxidative stress markers ${ }^{6}$; since lipid oxidation has been shown to be associated with damage at level of the cell membrane, this leads to apoptosis in a wide variety of cells. ${ }^{19-21}$ Therefore, protection from lipoperoxidation through antioxidants application, particularly antioxidants derived from medicinal plants, may be a possible strategy to protect cellular damage generated by oxidative stress. ${ }^{19-21}$

This study therefore aimed at evaluating protection from lipoperoxidation in erythrocytes and the antiinflammatory effect of E. canescens leaves ethanolic extract in mice.

\section{MATERIALS AND METHODS}

The study was conducted at the Pharmaceutical Research Center of the Faculty of Pharmacy and Biochemistry at Norbert Wiener University.

\section{Plant material and extract}

Plant species was collected in the province of Huaral, North of Lima to 250 m.s.n.m. The taxonomic

Cite this article: Fernández-Flores N, Rojas-Cardenas NF, Vásquez-Quispe AD, Chávez-Flores Juana E, Justil-Guerrero Hugo J, Parreño-Tipian JM, et al. Protection of Erythrocytes against Lipoperoxidation and Anti-inflammatory Effects of Ethanolic Extract of Encelia canescens Lam Leaves in Mice. Pharmacogn J. 2020;12(4):798-804. 
classification of the species was carried out at the Museo de Historia Natural of Universidad Nacional Mayor de San Marcos ( $\mathrm{N}^{\circ} 198-\mathrm{USM}-$ 2018). The process of obtaining the ethanolic extract from the $E$. canescens leaves was carried out in accordance with the stipulations of Lock O. (2016). ${ }^{22}$

\section{Phytochemistry analysis}

The process of phytochemistry analysis of ethanolic extract from the E. canescens leaves was carried out in accordance with coloring and precipitation techniques of Lock O. (2016). ${ }^{22}$

\section{Biological material}

For the evaluation of oxidative stress protection, a $2 \mathrm{~mL}$ sample of erythrocytes was obtained from rats of the Holtzman strain of 12 weeks of age weighting $220 \pm 10 \mathrm{~g}$ from Instituto Nacional de Salud (INS) and to evaluate the anti-inflammatory effect, male mice $25 \mathrm{~g}$ each, strain Balb/C53/CNPB was used. This study was approved by the Norbert Wiener University Ethics Committee under opinion $N^{\circ}$ 005-08-2019 FB/UPNW.

\section{Hemolysis and malondialdehyde quantification}

Erythrocytes protection from lipoperoxidation induced by $\mathrm{H}_{2} \mathrm{O}_{2}$ was evaluated by determining hemolysis and quantifying malondialdehyde (MDA) following the methods of Fátima et al. (2013) and Esterbauer and Cheeseman (1990) evaluating concentrations of 200, 100, 50 and $25 \mu \mathrm{g} / \mathrm{mL}$ of E. canescens. ${ }^{23,24}$

\section{Anti-inflammatory effect}

$1 \%$ carrageenan-induced air pouch model described by Duarte et al. (2016) was used, the inhibition of inflammation was measured with albumin, total protein and MDA parameters at concentrations of 100 , 250 and $500 \mathrm{mg} / \mathrm{kg}$ of E. canescens. ${ }^{25}$ Number and differentiation of leukocytes obtained from the exudate was determined by Wright staining as indicated by Mahat et al. (2010) with some modifications. ${ }^{26}$

\section{Histopathology}

Histopathological evaluation was performed as described by Fronza et al. (2016). The skin sections were fixed in Bouin's solution for 24 hours. Samples were dehydrated through graduated alcohol, clarified with xylene, and embedded in paraffin. $6 \mu \mathrm{m}$ thick sections were made and stained with hematoxylin-eosin (H\&E). ${ }^{27}$

\section{RESULTS}

E. canescens ethanolic extract was soluble in polar solvents and insoluble in apolar solvents. In addition, the presence of secondary metabolites such as flavonoids, phenolic compounds, and alkaloids was identified by qualitative analysis.

In the evaluation of erythrocyte protection against induced oxidative stress via $\mathrm{H}_{2} \mathrm{O}_{2}$, inhibition of hemolysis and release of MDA content depend on the concentration of the extracts, so concentration of 200 $\mu \mathrm{g} / \mathrm{mL}$ presented highest protection (Tables 1 and 2 and Figure 1).

Albumin, total proteins and MDA decreased significantly compared to the Control group $(p<0.05)$ (Table 3$)$ in the evaluation of biochemical parameters in air pouch exudate after carrageenan administration. Dexamethasone and E. canescens $500 \mathrm{mg} / \mathrm{kg}$ significantly decreased migration of polymorphonuclear leukocytes, monocytes, and lymphocytes compared to the control group (Table 4). All the treated groups showed a decrease in leukocyte migration, presence of fibroblasts and macrophages in histopathological evaluation, E. canescens $500 \mathrm{mg} /$ kg group standing out.

\section{DISCUSSION}

Secondary metabolites such as flavonoids, alkaloids, tannins, steroids and/or triterpenes were identified in this study. These metabolites have also been identified in Chile by Cayún et al. (2015), except for alkaloids; it seems that the climate and altitudinal floors in Peru are favorable for the development of these secondary metabolites. ${ }^{13,28}$ According to the reviewed literature, flavonoids, tannins, coumarins, steroids and/or

Table 1: Phytochemical analysis of the ethanolic extract of E. canescens leaves.

\begin{tabular}{lcc}
\hline Essays & Secondary metabolite & Ethanolic extract \\
\hline $\mathrm{FeCl}_{3}$ & Phenolic compounds & - \\
$\mathrm{AlCl}_{3}$ & Flavonoids & + \\
Shinoda & Flavonoids & + \\
$\mathrm{NaOH}$ gelatin & Tannins & + \\
Bertrand & Alkaloids & + \\
Dragendorff & Alkaloids & + \\
Mayer & Alkaloids & + \\
Popoff & Alkaloids & + \\
Wagner & Alkaloids & + \\
Liebermann - Burchard & Steroids and or triterpenes & - \\
Salkowski & Steroids & \\
\hline
\end{tabular}

Legend: Presence (+), absence (-).

Table 2: E. canescens protection in erythrocytes against $\mathrm{H} 2 \mathrm{O2}$-induced hemolysis at 30,60 and 90 minutes.

\begin{tabular}{lccc}
\hline \multirow{2}{*}{ Treatment } & \multicolumn{3}{c}{ Hemolysis inhibition (\%) } \\
\cline { 2 - 4 } & $\mathbf{3 0 ~ m i n}$ & 60 min & 90 min \\
\hline $\mathrm{H}_{2} \mathrm{O}_{2} 200 \mathrm{mmol}$ & - & - & - \\
Dexamethasone $200 \mu \mathrm{g} / \mathrm{mL}$ & $18.92^{\mathrm{a}}$ & $17.49^{\mathrm{a}}$ & $16.72^{\mathrm{a}}$ \\
E. canescens $200 \mu \mathrm{g} / \mathrm{mL}$ & $97.74^{\mathrm{b}}$ & $97.56^{\mathrm{b}}$ & $89.02^{\mathrm{b}}$ \\
E. canescens $150 \mu \mathrm{g} / \mathrm{mL}$ & $85.39^{\mathrm{c}}$ & $23.21^{\mathrm{c}}$ & $22.43^{\mathrm{c}}$ \\
E. canescens $100 \mu \mathrm{g} / \mathrm{mL}$ & $86.68^{\mathrm{d}}$ & $23.02^{\mathrm{d}}$ & $21.87^{\mathrm{c}}$ \\
E. canescens $50 \mu \mathrm{g} / \mathrm{mL}$ & $46.11^{\mathrm{e}}$ & $20.05^{\mathrm{d}}$ & $21.58^{\mathrm{c}}$ \\
E. canescens $25 \mu \mathrm{g} / \mathrm{mL}$ & $3.97^{\mathrm{f}}$ & $3.91^{\mathrm{e}}$ & $7.35^{\mathrm{d}}$ \\
\hline
\end{tabular}

The results in each period $(n=3)$; different letters in each column indicate significant difference $(p<0.05)$, equal letters indicate that there is no difference between groups. 
Table 3: Effect of E. canescens on biochemical parameters in air pouch exudate after administration of carrageenan at $1 \%$.

\begin{tabular}{lccc}
\hline \multirow{2}{*}{ Group $(\mathrm{n})$} & Albumin & Total proteins & MDA \\
\cline { 2 - 4 } & $(\mathrm{g} / \mathrm{dL})$ & $(\mathrm{g} / \mathrm{dL})$ & $(\mathrm{nmol} / \mathrm{mL})$ \\
\hline Observer & $0.26^{\mathrm{a}}$ & $2.13^{\mathrm{a}}$ & $1.12^{\mathrm{a}}$ \\
Control & 1.84 & 5.31 & 1.67 \\
Dexamethasone $2 \mathrm{mg} / \mathrm{kg}$ & $1.21^{\mathrm{a}}$ & $3.57^{\mathrm{a}}$ & $1.44^{\mathrm{a}}$ \\
E. canescens $100 \mathrm{mg} / \mathrm{kg}$ & $1.65^{\mathrm{a}}$ & $4.58^{\mathrm{a}}$ & $1.57^{\mathrm{a}}$ \\
E. canescens $250 \mathrm{mg} / \mathrm{kg}$ & $1.48^{\mathrm{a}}$ & $4.15^{\mathrm{a}}$ & $1.45^{\mathrm{a}}$ \\
E. canescens $500 \mathrm{mg} / \mathrm{kg}$ & $1.01^{\mathrm{a}}$ & $3.67^{\mathrm{a}}$ & $1.24^{\mathrm{a}}$ \\
\hline
\end{tabular}

In each column $(n=6)$, a: indicates a significant difference $(p<0.05)$ compared to the control group (carrageenan at $1 \%)$.

Table 4: Effect of E. canescens on leukocyte infiltration in air pouch exudate after administration of carrageenan at $1 \%$.

\begin{tabular}{|c|c|c|c|c|}
\hline \multirow[b]{2}{*}{ Treatment } & \multirow{2}{*}{$\begin{array}{l}\text { Leukocytes } \\
x \mathrm{~mm}^{3}\end{array}$} & \multicolumn{3}{|c|}{ Leukocyte differentiation } \\
\hline & & $\begin{array}{l}\text { Polymorphonuclear } \\
\times 10^{3} / \mathrm{mm}^{3}\end{array}$ & $\begin{array}{l}\text { Monocytes } \\
\times 10^{3} / \mathrm{mm}^{3}\end{array}$ & $\begin{array}{l}\text { Lymphocytes } \\
\times 10^{3} / \mathrm{mm}^{3}\end{array}$ \\
\hline Observer & 0 & 0 & 0 & 0 \\
\hline Control & 24.16 & 15.56 & 2.72 & 5.88 \\
\hline Dexamethasone $2 \mathrm{mg} / \mathrm{kg}$ & $4.15^{\mathrm{a}}$ & $2.81^{\mathrm{a}}$ & $0.46^{\mathrm{a}}$ & $0.89^{\mathrm{a}}$ \\
\hline E. canescens $500 \mathrm{mg} / \mathrm{kg}$ & $4.57^{\mathrm{a}}$ & $2.80^{\mathrm{a}}$ & 0.84 & $0.93^{\mathrm{a}}$ \\
\hline E. canescens $250 \mathrm{mg} / \mathrm{kg}$ & 6.98 & 4.08 & 1.27 & 1.62 \\
\hline E. canescens $100 \mathrm{mg} / \mathrm{kg}$ & 8.38 & 4.14 & 1.80 & 2.44 \\
\hline
\end{tabular}

In each column $(n=6)$, a: indicates a significant difference $(p<0.05)$ compared to the control group (carrageenan at $1 \%)$.

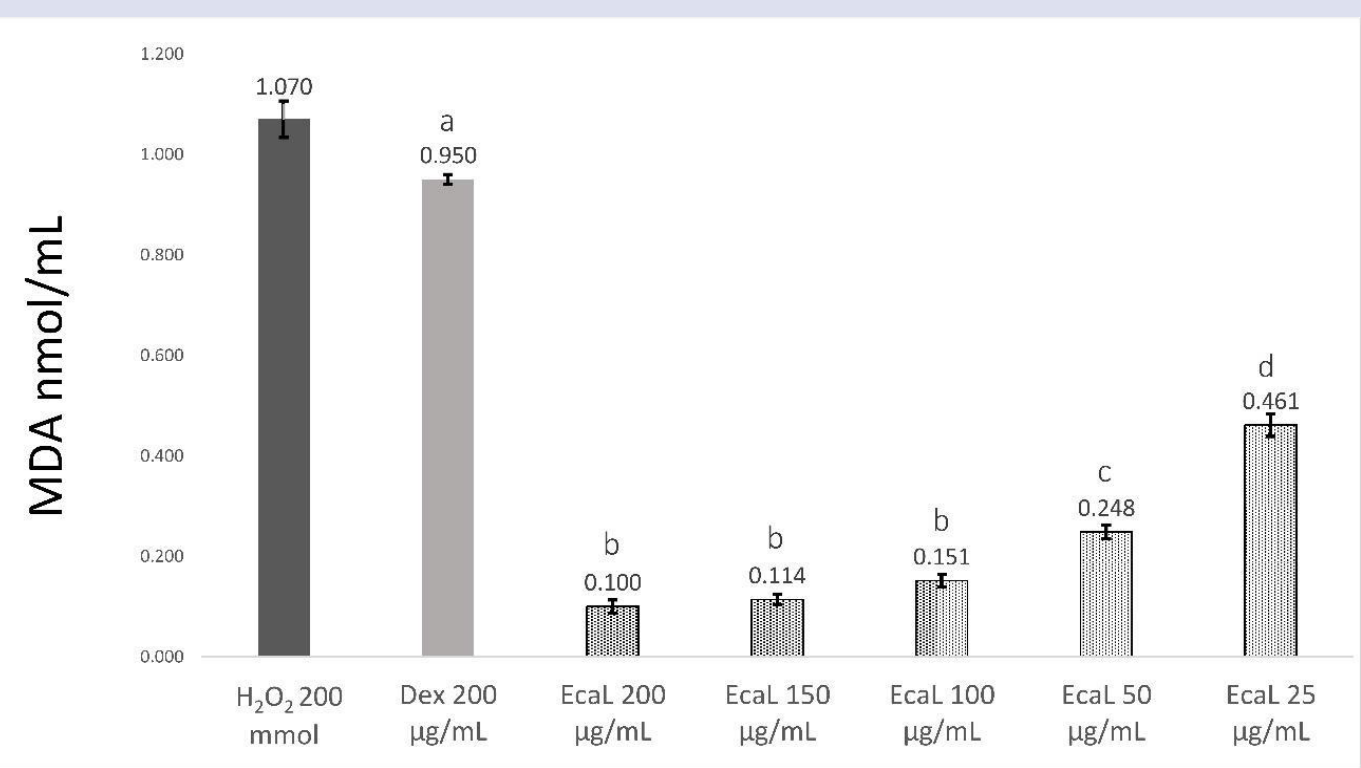

Figure 1: Results $(n=3)$ of MDA concentration expressed in $\mathrm{nmol} / \mathrm{mL}$ of erythrocytes subjected to oxidative stress with $\mathrm{H} 2 \mathrm{O} 2$; letters $\mathrm{a}, \mathrm{b}, \mathrm{c}$, $d$ indicate significant difference $(\mathrm{p}<0.05)$ compared to the $\mathrm{H} 2 \mathrm{O} 2$ group; equal letters indicate that there is no difference between groups. EcaL: E. canescens.

triterpenes are metabolites that have demonstrated anti-inflammatory and antioxidant effects, contributing to the prevention of chronic diseases of higher prevalence. ${ }^{29,30}$

In Table 2, E. canescens $200 \mu \mathrm{g} / \mathrm{mL}$ presented greater protection against hemolysis compared to the $\mathrm{H}_{2} \mathrm{O}_{2}$ control group $(\mathrm{p}<0.05)$ at the three-time marks (30, 60 and 90 min). Radical $\mathrm{H}_{2} \mathrm{O}_{2}$ oxidizes the ferrous ion of hemoglobin to ferric, producing methemoglobin in the Fenton reaction, generating hydroxyl ion $(\bullet \mathrm{OH})^{31}$, a reactive species capable of damaging DNA, lipids, and cell proteins, among others. ${ }^{32}$ Secondary metabolites with antioxidant properties transfer electrons to the hydroxyl ion causing reduction of the ferric ion and stabilizing hemoglobin, preventing hemolysis and restoring the balance of the plasma membrane in erythrocytes. ${ }^{33}$
In Figure 1, the concentration of MDA in erythrocytes is shown after having been exposed to oxidative stress with $\mathrm{H}_{2} \mathrm{O}_{2}$, concentration-dependent MDA decrease of $E$. canescens extracts is evidenced, showing a significant difference with the $\mathrm{H}_{2} \mathrm{O}_{2}$ group, the one in which the concentration of 200 $\mu \mathrm{g} / \mathrm{mL}$ stands out. Lipoperoxidation occurs in the erythrocyte membrane and MDA is an indicator of this phenomenon, which is mediated by inflammatory processes that will damage cellular components as well as increased levels of hydroxyl radical $(\bullet \mathrm{OH})$, superoxide $\left(\mathrm{O}^{2-}\right)$, radicals derived from nitrogen (NO) which destabilize the cell membrane. ${ }^{34-36}$ In this sense, E. canescens extract stabilizes the radicals that will cause lipoperoxidation as it is an electron donating compound.

Table 3 shows that albumin, total proteins and MDA differ significantly from carrageenan $1 \%(\mathrm{p}<0.05)$. This is because flavonoids act by 


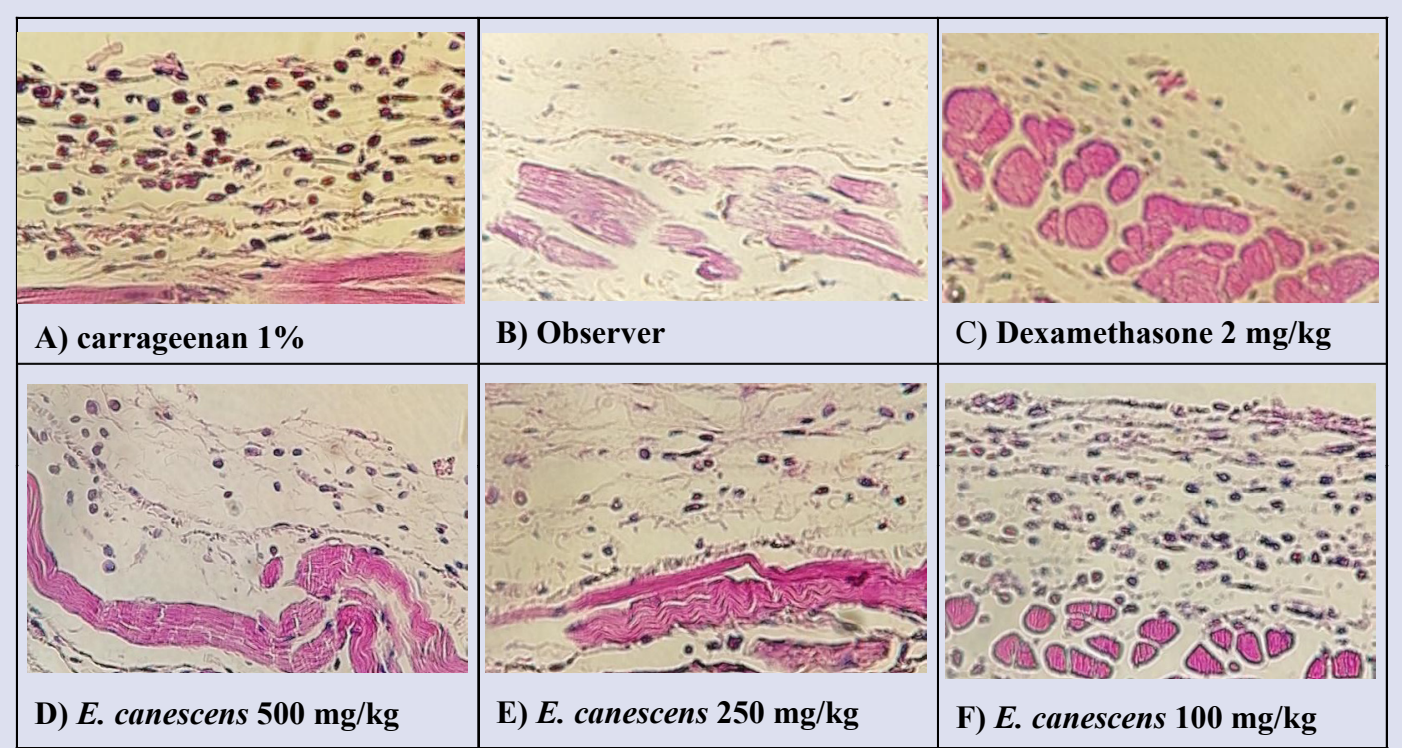

Figure 2: Effect of dexamethasone and $\mathrm{E}$. canescens on leukocyte migration, presence of macrophages in the hypodermis in the air pouch after administering carrageenan 1\% (photomicrographs increased by $40 \mathrm{x}$, staining: H-E). Where: A: Dense and organized layer of macrophages, leukocytes and fibroblast cells; B: Presence of fibroblasts, macrophages in minimal quantity; C: Presence of leukocytes, fibroblasts and macrophages in lower density than in carrageenan 1\%; D and E: Presence of leukocytes, fibroblasts and macrophages in lower density than in carrageenan $1 \%$ and similar to Dexamethasone $2 \mathrm{mg} / \mathrm{kg}$; and F: Presence of leukocytes, fibroblasts and macrophages in lower density than carrageenan 1\%, but higher density than Dexamethasone $2 \mathrm{mg} / \mathrm{kg}$, E. canescens $500 \mathrm{mg} / \mathrm{kg}$ and E. canescens $250 \mathrm{mg} / \mathrm{kg}$

inhibiting the lipoxygenase pathway 5 which prevents the inflammation cascade from forming and prevents the release of inflammation mediators. ${ }^{37,38}$ Furthermore, steroids participate by inhibiting the inflammatory process, since they stabilize the lysosome membrane, intracellular particles that contain proteases and hydrolytic enzymes which form inflammation chemical mediators, preventing the disintegration of said lysosomes that are produced in inflammatory processes and are responsible for damage and other inflammatory phenomena. ${ }^{39}$ When evaluating the biochemical parameters, E. canescens $500 \mathrm{mg} / \mathrm{kg}$ presented better results, showing that the higher the concentration, greater anti-inflammatory effect. Cochachi and Fernández (2015), had similar results when evaluating the ethanolic extract of the stems of $E$. canescens where they found a total proteins and albumin decrease, being attenuated after the administration of the treatment groups, being attenuated after the administration of the treatment groups, being most activity concentration was $400 \mathrm{mg} /$ $\mathrm{kg}$ with similar activity to silymarin $300 \mathrm{mg} / \mathrm{kg}$ but, in this study was not evaluated anti-inflammatory activity. ${ }^{40}$ Finally, Chilquillo and Cervantes (2017), demonstrated that the hydroalcoholic extract from the leaves of Senecio canescens (Humb. \& Bonpl.) Cuatrec "vira-vira" present favorable results of MDA in blood, noting a significant decrease in MDA values in the groups to which the treatment was administered compared to the stress group ${ }^{41}$, this is according with the results obtained in the present research work.

Table 4 shows leukocyte migration evaluation in the exudate, $E$. canescens $500 \mathrm{mg} / \mathrm{kg}$ showed decreased migration of lymphocytes and polymorphonuclear cells. They participate in phagocytosis by releasing superoxide and hydrogen peroxide free radicals to produce a hydroxyl radical, which attacks leukocytes and leads to premature cell death. ${ }^{25}$ Likewise, an increase in lymphocytes and monocytes was observed, being greater in the E. canescens $100 \mathrm{mg} / \mathrm{kg}$ treatment, which means that these leukocytes would be responsible for phagocytosis or macrocytosis of apoptotic neutrophils. Leukocyte migration to the area of injury causes leukocytes to engulf pathogens, destroy bacteria and microorganisms, and degrade necrotic tissue, but can also prolong tissue injury by releasing enzymes, chemical mediators, and reactive species from the oxygen (oxygen free radicals, RLO). ${ }^{42}$

The anti-inflammatory effect of E. canescens was examined histologically (Figure 2), in the normal tissue (observer) inflammation was not evidenced where a layer of flattened cells superimposed on loose vascular connective tissue is observed. In carrageenan $1 \%$ group, macrophages and fibroblasts increased in the lining layer of flattened cells in the groups, observing inflammatory changes such as leukocyte infiltration and edema (evidenced by tissue thickening). E. canescens $500 \mathrm{mg} / \mathrm{kg}$ significantly reduced inflammatory changes with less edema and cell infiltration. The anti-inflammatory potency of the extract 500 $\mathrm{mg} / \mathrm{kg}$ was related to the lower leukocyte migration in the exudate and the lower concentration of MDA.

Although the relationship between chemical composition and activity has not been established, some reported compounds may be responsible for the activity. Bohlmann et al (1982) reported presence aromatic compounds like p-hydroxyacetophenone derivatives, p-hydroxyacetophenone-derived compounds probably be related to anti-inflammatory activity by being closely related to cyclooxygenase inhibitors structure. ${ }^{14,43}$ Anti-inflammatory activity by others acetophenones derivative had be reported. ${ }^{44-46}$

\section{CONCLUSION}

Under experimental conditions, the ethanolic extract of Encelia canescens Lam leaves protects erythrocytes from lipoperoxidation induced via $\mathrm{H}_{2} \mathrm{O}_{2}$ and presents an anti-inflammatory effect at dosedependent in carrageenan 1\%-induced airbag model, maybe for presence of p-hydroxyacetophenone-derived. These could be new safer anti-inflammatories drugs but it's necessary more studies to support the effectiveness and safety of the use of extracts of this plant.

\section{CONFLICTS OF INTEREST}

The authors declare no conflicts of interest in this study. 
Fernández-Flores $\mathrm{N}$ et al.: Protection of Erythrocytes against Lipoperoxidation and Anti-inflammatory Effects of Ethanolic Extract of Encelia canescens Lam Leaves in Mice

\section{ETHICAL APPROVAL}

This study was approved by the Norbert Wiener University Ethics Committee under opinion $\mathrm{N}^{\circ} 005-08-2019 \mathrm{FB} / \mathrm{UPNW}$.

\section{REFERENCES}

1. Kim HC, Oh SM. Noncommunicable diseases: Current status of major modifiable risk factors in Korea. J Prev Med Public Heal. 2013;46(4):165-72.

2. Villalpando S, Rull J. The status of non-transmissible chronic disease in Mexico based on the National Health and Nutrition Survey 2006. Salud Publica Mex. 2010;52(1):S2-3.

3. Bujosa F. Economic development and disease. Lancet. 1999; 354(SIV19).

4. Luther J, Dave M. Rising Inflammatory Bowel Disease Prevalence Highlights the Need for Effective, Cost-Effective Therapies. Inflamm Bowel Dis. 2020:26(4):626-27.

5. Pizzi C, Xhyheri B, Costa G, Manzoli L. Depression, heart rate variability inflammation, and incident cardiovascular disease in subjects with coronary heart disease risk factors. Heart disease, environmental, psycho-social, cultural, occupational factors Methods. 2018;P1519:316.

6. Beaglehole R, Bonita R, Horton R, Adams C, Alleyne G, Asaria P, et al. Priority actions for the non-communicable disease crisis. Lancet. 2011;377(9775):143847.

7. Liguori I, Russo G, Curcio F, Bulli G, Aran L, Della-Morte D, et al. Oxidative stress, aging, and diseases. Clin Interv Aging. 2018:13:757-72.

8. Figueroa R, Tamayo J, González S, Moreno G, Vargas L. Actividad antioxidante de antocianinas presentes en cáscara de pitahaya (Hylocereus undatus). Rev Iber Tecnología Postcosecha. 2011:12(1):44-50.

9. García B, Saldaña A Saldaña L. El estrés oxidativo y los antioxidantes en la prevención del cáncer. Rev Haban Cienc Méd. 2013:12(2):187-96.

10. Ulloa C, Acevedo-Rodríguez P, Beck S, Belgrano MJ, Bernal R, Berry PE, et al. An integrated assessment of the vascular plant species of the Americas. Science. 2017:358(6370):1614-7.

11. Quevedo E, Quevedo C, Quiñones L. Compositions, products, therapeutic uses and procedures for the production and/or crystallization of extracts of Encelia canescens Lam (coronilla de fraile). United States Patent 8663715. Mar. 4, 2014

12. Araujo B, Ramos G, Flores M. Plantas medicinales utilizadas en la salud reproductiva de las mujeres del Perú. Dominguezia. 2019;35(1):5-74

13. Cayun JP, Zamorano J, Quiñones L, Valera NM, Squicciarini V, Larenas HD, et al. Preclinical Evaluation of the Encelia canescens Lam Extract: Medicinal Properties useful for Cancer Treatment. J Nat Remedies. 2015;15(2):113-24.

14. Bohlmann F, Tsankova E, Jakupovic J, King RM, Robinson H. Dimeric chromenes and mixed dimers of a chromene with euparin from Encelia canescens. Phytochemistry. 1983;22(2):557-60.

15. Álvarez E, Orallo F. Actividad biológica de los flavonoides (I). Acción frente al cáncer. Ámbito Farmacéutico. 2003;22(10): 130-40.

16. Pan $\mathrm{MH}$, Lai CS, Ho CT. Anti-inflammatory activity of natural dietary flavonoids. Food Funct. 2010;1:15-31.

17. Sun Y, Gao LL, Tang MY, Feng BM, Pei YH, Yasukawa K. Triterpenoids from Euphorbia maculata and Their Anti-Inflammatory Effects. Molecules. 2018:23(9):2112

18. Wu P, Gao H, Liu JX, Liu L, Zhao H, Liu ZQ. Triterpenoid saponins with anti-inflammatory activities from llex pubescens roots. Phytochemistry. 2017:134:122-32.

19. Momeni HR, Eskandari N. Effect of curcumin on kidney histopathological changes, lipid peroxidation and total antioxidant capacity of serum in sodium arsenite-treated mice. Exp Toxicol Pathol. 2017;69(2):93-7.

20. Dairi S, Carbonneau MA, Galeano-Diaz T, Remini H, Dahmoune F, Aoun O et al. Antioxidant effects of extra virgin olive oil enriched by myrtle phenolic extracts on iron-mediated lipid peroxidation under intestinal conditions model. Food Chem. 2017;237:297-304.

21. Bridi R, Giordano A, Peñailillo MF, Montenegro G. Antioxidant effect of extracts from native Chilean plants on the lipoperoxidation and protein oxidation of bovine muscle. Molecules. 2019:24(18): E3264.

22. Lock O. Investigación Fitoquímica. Métodos en el estudio de productos naturales. 3ra ed. Lima: PUCP; 2016.
23. Fatima M, Kesharwani RK, Misra K, Rizvi SI. Protective effect of theaflavin on erythrocytes subjected to in vitro oxidative stress. Biochem Res Int. 2013:2013:649759.

24. Esterbauer $\mathrm{H}$, Cheeseman $\mathrm{KH}$. Determination of aldehydic lipid peroxidation products: Malonaldehyde and 4-hydroxynonenal. Methods Enzymol. 1990;186:407-21.

25. Duarte DB, Vasko MR, Fehrenbacher JC. Models of inflammation: Carrageenan air pouch. Curr Protoc Pharmacol. 2012;5:5.6.1-5.6.8.

26. Mahat MYA, Kulkarni NM, Vishwakarma SL, Khan FR, Thippeswamy BS Hebballi $V$, et al. Modulation of the cyclooxygenase pathway via inhibition of nitric oxide production contributes to the anti-inflammatory activity of kaempferol. Eur J Pharmacol. 2010;642(1-3):169-76.

27. Fronza M, Muhr C, da Silveira DSC, Sorgi CA, Rodrigues SF de P, Farsky SHP et al. Hyaluronidase decreases neutrophils infiltration to the inflammatory site. Inflamm Res. 2016;65(7):533-542

28. Zepúlveda RA. Estudio fitoquímico y farmacológico de Encelia canescens Lam. Asteraceae. Bachelor's Thesis, Facultad de Ciencias Químicas y Farmacéuticas, Universidad de Chile, Santiago de Chile, Chile, 2007

29. Hämäläinen $M$, Nieminen $R$, Vuorela $P$, Heinonen $M$, Moilanen E. Antiinflammatory effects of flavonoids: genistein, kaempferol, quercetin, and daidzein inhibit STAT-1 and NF-kappaB activations, whereas flavone, isorhamnetin, naringenin, and pelargonidin inhibit only NF-kappaB activation along with their inhibitory effect on iNOS expression and NO production in activated macrophages. Mediators Inflamm. 2007;2007:45673.

30. Middleton E, Kandaswami C, Theoharides TC. The effects of plant flavonoids on mammalian cells: Implications for inflammation, heart disease, and cancer. Pharmacol Rev. 2000;52(4):673-751.

31. Stocks J, Dormandy TL. The Autoxidation of Human Red Cell Lipids Induced by Hydrogen Peroxide. Br J Haematol. 1971;20(1):95-111.

32. Younus $\mathrm{H}$. Therapeutic potentials of superoxide dismutase. Int J Health Sci (Qassim). 2018;12(3):88-93

33. Xu DP, Li Y, Meng X, Zhou T, Zhou Y, Zheng J, et al. Natural antioxidants in foods and medicinal plants: Extraction, assessment and resources. Int $\mathrm{J}$ Mol Sci. 2017:18(1):E96.

34. Hamid HK, Kadhim EJ. Extraction, isolation and characterization of Pyrrolizidine Alkaloids present in Senecio vulgaris Linn grown in Iraq. J Pharmacogn Phytochem. 2016:5(6):28-37.

35. Halliwell B, Gutteridge JM. The definition and measurement of antioxidants in biological systems. Free Radic Biol Med. 1995;18(1):125-6.

36. Toyokuni S. Reactive oxygen species-induced molecular damage and its application in pathology. Phathology Int. 1999;49(2):91-102

37. Tasayco NJ, Álvares HR, Pizarro J, Vega L, Gaspar K, García C. Seguridad y efecto antiinflamatorio del extracto hidroalcohólico de las hojas de Senna alata (L.) Roxb (dormilona) en ratas con inducción a inflamación aguda. Bachelor's Thesis, Farmacología y Farmacia, Universidad Interamericana para el Desarrollo, Lima, Perú, 2019.

38. Acostupa F de M, Chávez A, Mejía SE, Pauta MM, Tucunango JL. Efecto antiinflamatorio in vitro de los extractos etanólicos de cuatro plantas medicinales peruanas. Rev Peru Med Integrativa. 2017;2(2):79-85.

39. Schimmer BP, Funder JW. Adrenocorticotropic Hormone, Adrenal Steroids, and the Adrenal Cortex In: Brunton LL, Chabner BA, Knollmann BC. Goodman \& Gilman's: The Pharmacological Basis of Therapeutics, 13e. United States of America: McGraw-Hill Education, p. 845-61; 2018.

40. Cochachi Y, Fernández DL. Toxicidad aguda y efecto hepatoprotector de extracto etanólico de los tallos de Encelia canescens Lamarck. en ratas en un modelo de intoxicación con paracetamol. Bachelor's Thesis, Facultad de Farmacia y Bioquímica, Universidad Nacional San Luis Gonzaga, Ica, Perú 2015

41. Chilquillo HM Cervantes RG. Efecto antiinflamatorio, analgésico y antioxidante del extracto hidroalcohólico de las hojas de Senecio canescens (Humb. \& Bonpl.) Cuatrec. "vira-vira". Bachelor's Thesis, Facultad de Farmacia y Bioquímica, Universidad Nacional Mayor de San Marcos, Lima, Perú, 2017.

42. León ML, Alvarado A, De Armas JO, Miranda L, Varens JA, Cuesta JA Respuesta inflamatoria aguda. Consideraciones bioquímicas y celulares. Rev Finlay. 2015;5(1):47-62

43. Harusawa S, Nakamura S, Yagi S, Kurihara T, Hamada Y, Shioiri T. A new synthesis of some non-steroidal anti-inflammatory agents via cyanophosphate. Synth Commun. 1984;14(14):1365-71. 
Fernández-Flores $\mathrm{N}$ et al.: Protection of Erythrocytes against Lipoperoxidation and Anti-inflammatory Effects of Ethanolic Extract of Encelia canescens Lam Leaves in Mice

44. Favier L, Tonn C, Guerreiro E, Rotelli A, Pelzer L. Anti-inflammatory activity acetophenones from Ophryosporus. Planta Med. 1998;64:657-59.

45. Chen JJ, Cho JY, Hwang TL, Chen IS. Benzoic acid derivatives, acetophenones, and anti-inflammatory constituents from Melicope semecarpifolia. J Nat Prod. $2008 ; 71(1): 71-5$
46. Müller AA, Reiter SA, Heider KG, Wagner H. Plant-derived acetophenones with antiasthmatic and anti-inflammatory properties: Inhibitory effects on chemotaxis, right angle light scatter and actin polymerization of polymorphonuclear granulocytes. Planta Med. 1999;65:590-4.

\section{GRAPHICAL ABSTRACT}

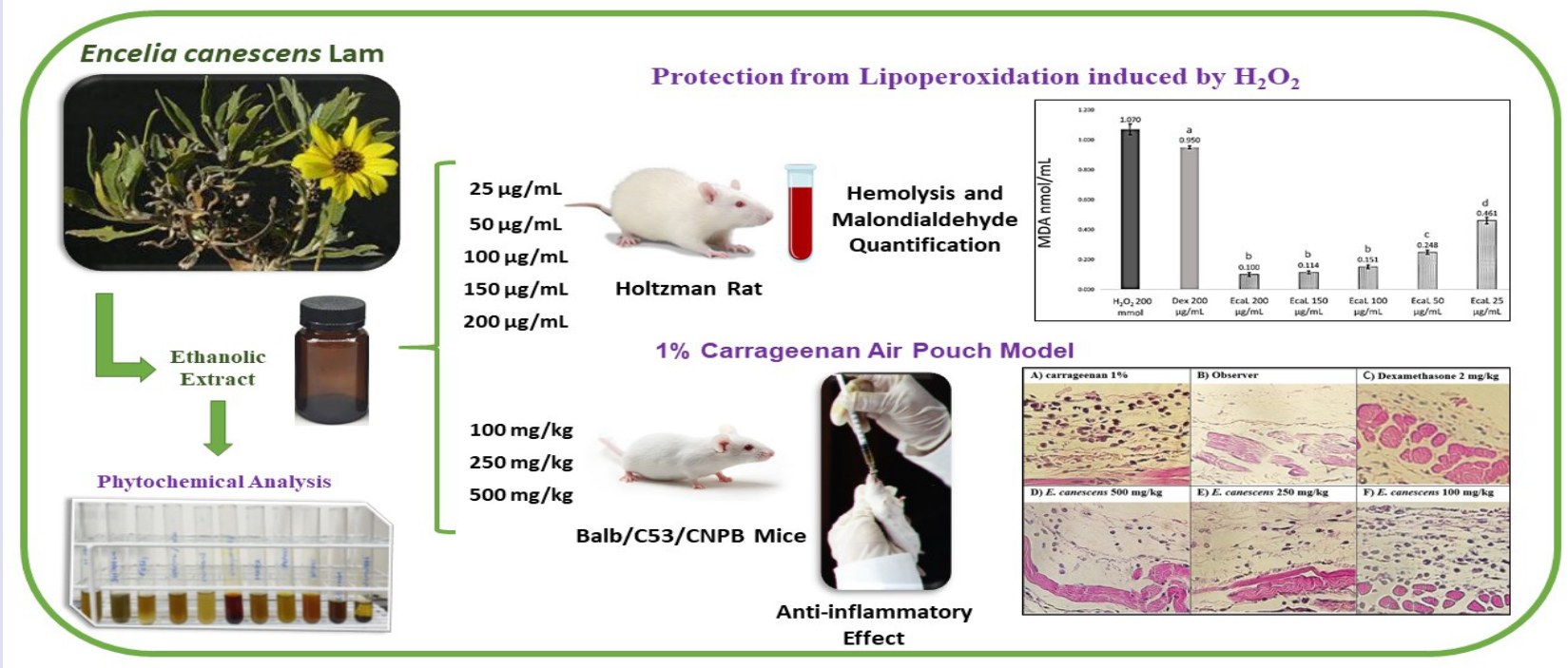

\section{ABOUT AUTHORS}

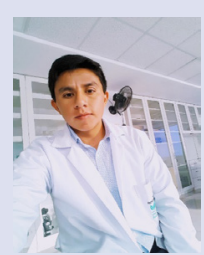

Fernández-Flores Nélber. Student of Pharmacy and Biochemistry at Universidad Norbert Wiener. He is part of merit school for being awarded the "Alcibiades Horna Figueroa" scholarship. Researcher at Centro de Investigación Farmacéutica of the same university, Asociación Peruana de Estudiantes de Farmacia y Bioquímica (APEFYB). He has been part of the research seedbed group since 2017. He participated as an assistant and speaker at Congreso Nacional Peruano de Estudiantes de Farmacia y Bioquímica (CONAPEFYB), scientific meetings and institutional symposiums obtaining different recognitions. He is currently practicing in pharmaceutical care.

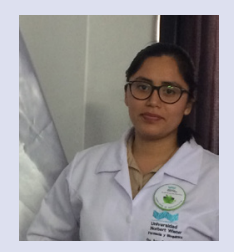

Rojas-Cardenas Nathalie F. She has been part of the research seedbed group of Universidad Norbert Wiener since 2017. Researcher at the Pharmaceutical Research Center of the same university. She participated as an assistant and speaker at Congreso Nacional Peruano de Estudiantes de Farmacia y Bioquímica (CONAPEFYB), scientific meetings and institutional symposia obtaining different recognitions. She currently works in pharmaceutical industry.

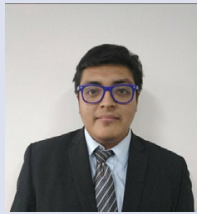

Vásquez-Quispe Ángel D. He has been part of the research seedbed group of Universidad Norbert Wiener since 2017. Researcher at the Pharmaceutical Research Center of the same university. He participated as an assistant and speaker at Congreso Nacional Peruano de Estudiantes de Farmacia y Bioquímica (CONAPEFYB), scientific meetings and institutional symposia obtaining different recognitions. He currently works as a clinical pharmacy assistant.

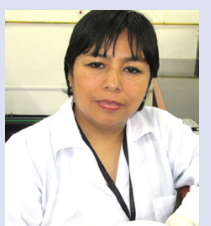

Chávez-Flores Juana E. Doctor in Pharmacy and Biochemistry (2011) and Master in Experimental Pharmacology (2007), both of Universidad Nacional Mayor de San Marcos. Pharmacist by Universidad Norbert Wiener (2004), she did an international internship (2020) at the Laboratory of Cellular Biology and Genotoxicology - Universidad Técnica Particular de Loja - Ecuador, participates in phytochemical, pharmacological and toxicological research projects, teacher and researcher, co-organizer of $\mathrm{ECl}$ : International Scientific Meeting, member of the "Centro Peruano de Investigación y Desarrollo de Recursos Naturales en Salud INKA HAMPI". 


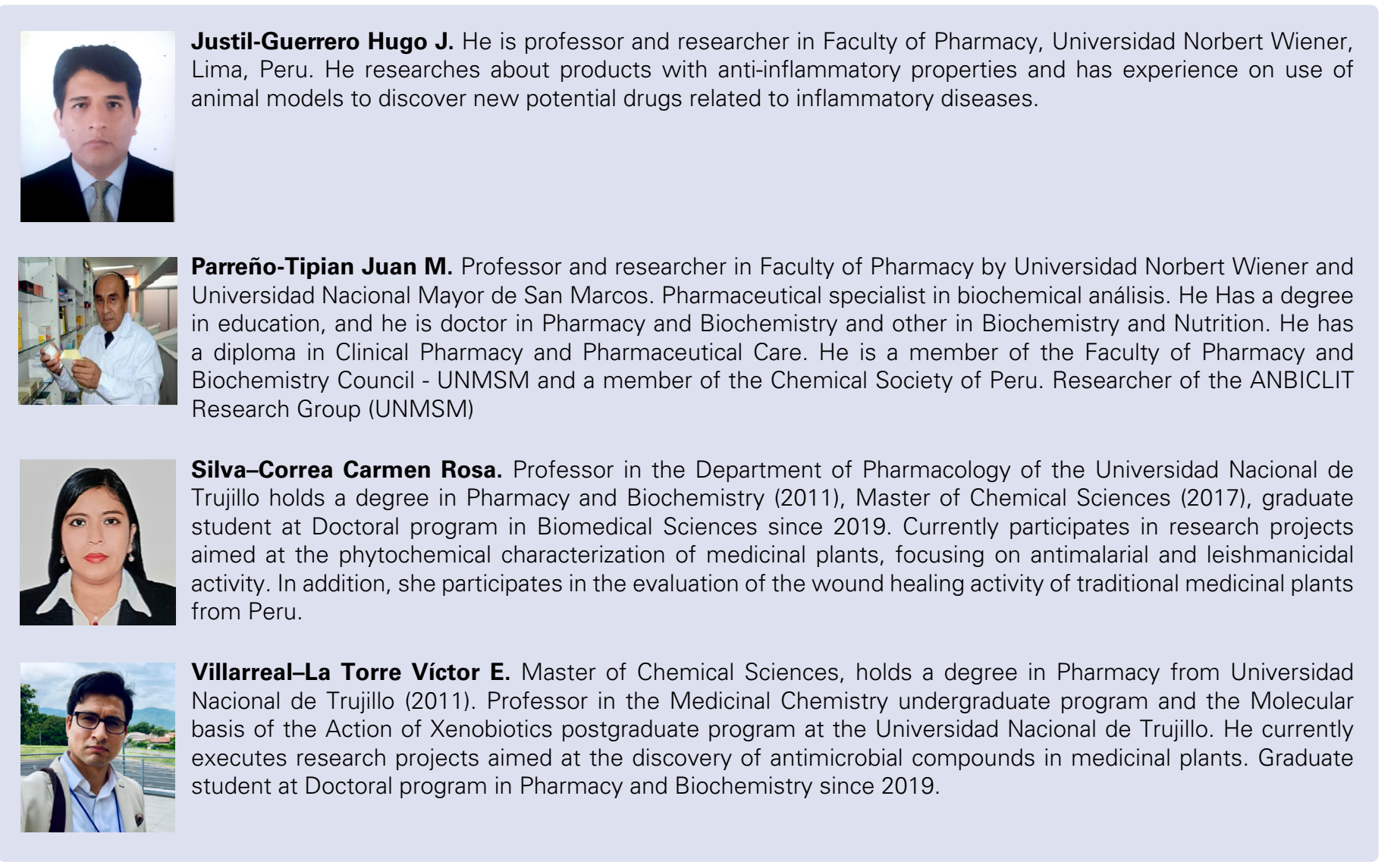

Cite this article: Fernández-Flores N, Rojas-Cardenas NF, Vásquez-Quispe AD, Chávez-Flores Juana E, Justil-Guerrero Hugo J, Parreño-Tipian JM, et al. Protection of Erythrocytes against Lipoperoxidation and Anti-inflammatory Effects of Ethanolic Extract of Encelia canescens Lam Leaves in Mice. Pharmacogn J. 2020;12(4):798-804. 